\title{
The Development of Assessment Instrument Models of Malay Dance Art
}

\author{
Dilinar Adlin ${ }^{1, *}$ Julaga Situmorang ${ }^{2}$ Abdul Hasan Saragih ${ }^{3}$ \\ ${ }^{123}$ State University of Medan, Medan, Indonesia \\ *Corresponding author. Email: dilinaradlinmpd@gmail.com
}

\begin{abstract}
The purpose of this study was to determine and analyze: (1) the appropriateness of the Malay dance assessment instrument model to measure dance competency, (2) the validity and reliability of the dance assessment instrument model, and (3) the effectiveness of the Malay dance assessment instrument model to measure artistic competence dance. The research method used is development research. The resulting assessment tool was validated by an expert, then, continued with individual tests, small group tests and field groups. Testing the effectiveness of the learning model is done by testing the $t$ test statistic. The research findings show: (1) the model of the Malay dance assessment instrument was developed starting from the needs analysis, design, evaluation and trial stages to produce model books, instructor manuals and assessment instruments for Malay dance that have been validated by experts and the results show the level of feasibility to be used for measuring the competence of dance, (2) the dance assessment instrument developed has a high level of validity and reliability, and (3) the dance assessment instrument model is proven to be effective, this can be seen from the results of statistical testing where the calculated price is known $(5,60)$ $>t_{\text {table }}$ (1.99), so it can be concluded that the assessment instrument model is effective for measuring the competence of dance
\end{abstract}

Keywords: Assessment Instrument Models, Malay Dance Art.

\section{INTRODUCTION}

The body text starts with a standard first-level The quality and success of the assessment in principle depends on the quality of the design of the assessment itself. Therefore, it is really naive if the assessment is carried out without a clear assessment design, it is even ironic if the assessment is carried out without any assessment design at all or flows as it is. Therefore, the development of an assessment model is an urgent matter in assessing dancing competence, this is confirmed by Triana (2014) in her research which finds that dance assessment has specific characteristics and must be understood in terms of the purpose, type of dance, and the form of dance performance that is displayed. Furthermore, Anggraini and Hasnawati (2016) asserted that in dance learning, the assessment is not whether the dance produced is good or not, but is the creative process that they go through until a positive attitude is formed through dance learning. For example, confident, able to work together, dare to make decisions, able to socialize, able to express opinions and so on.
It is likewise, Putri and Yanuartuti's research (2018) found that authentic assessment in dance learning is in the form of a work test or practical test in which each student individually or in groups performs dance movements to dance works as a whole. This is confirmed by the research findings of Nurnaningsih et al (2018) that the assessments made by teachers so far are by looking at the elements of wiraga, wirama, and wirasa. In wiraga what is seen is the movement is carried out according to what has been taught or not. Furthermore, in wiraga what is seen is the accompaniment of singing according to the beat, and in wirasa what is seen is the appreciation of dance.

Furthermore, Triana's research (2012) shows: (1) kinesthetic intelligence in arranging dance which is given an assessment of process performance is lower than kinesthetic intelligence in arranging dance which is given an assessment of product performance, especially for the group with high mastery of dance composition knowledge, and (2) kinesthetic intelligence. in arranging dance, the process performance assessment was higher than the kinesthetic intelligence in arranging dance, the product performance assessment was given, especially 
for the group with low mastery of dance composition knowledge,

Several studies related to Malay dance include: (1) Pasaribu's research (2017) showing learning through audiovisual media on dance assessments for students is in the good category with an average value (mean) of $76.75 \%$, as many as 8 people or $25 \%$ got the very good category, as many as 20 people or $62.5 \%$ got the good category, as many as 4 people or $12.5 \%$ got the sufficient category, (2) Ruslan's research (2018) shows the use of this Malay dance video media, is considered successful increase the motivation and learning outcomes of students' dance art. (3) Evadila's research (2017) related to the Malay dance Zapin Pecah Dua Belas found that there are five unique features, namely: (a) totality; (b) harmony (harmony) (c) symmetry (symmetry); (d) balance (balance); and (e) opposition, resistance, contradiction, contained in the form of movement, and the dynamics of the motion, and (4) Zulfahmi's research (2016) shows the similarities of several Malay dances not in terms of the form of movement but rather on their use in the middle of the dance. the society in which the dance is created is to describe the social system prevailing in the society.

In connection with this idea, the dance assessment model is an important thing to develop, because the assessment of students' competence in mastering Malay dance uses a dance assessment format in general, namely using the wiraga, wirama, and wirasa formats or known as $3 \mathrm{~W}$. Whereas, Malay dances have different characteristics from dances in general, in this case Malay dances can be seen from the perspective of harmony, rentak, rasa, resam and ribus or what is known as the $5 R$

\section{LITERATURE REVIEW}

An assessment instruments are tools and procedures used to collect and interpret competency facts. In other words, an assessment instrument is a specific activity or question that is used to assess competence using the selected assessment method (Yaumi, 2015: 183). Supardi (2015:43) explains that the assessment instrument is a tool used to measure the mastery of students' competencies including the competence of cognitive dimensions, affective dimensions and psychomotor dimensions.

A good assessment instrument meets several criteria, in this case Yusuf (2015) explains the criteria for a good instrument, namely: valid, reliable, objective, and practical. The same thing is explained by Arikunto (2010) related to the criteria for the assessment instrument that must meet the following requirements: validity, reliability, objectivity, practicability, and economy. Furthermore, Kunandar (2013: 82) explains the characteristics of a good assessment instrument criteria as follows: valid, reliable, relevant, representative, practical, discriminatory, specific, and proportional.

The steps for developing an assessment instrument are as follows: (1) determining the purpose of the assessment, (2) determining the competence or ability to be tested, (3) determining the essential materials or materials to be tested, (4) making a specification table for the distribution of the assessment instrument, ( 5) making an assessment instrument grid, (6) an analysis of the lattice, (7) the preparation of the assessment instrument items, (8) an analysis of the assessment instrument items, and (9) testing the assessment instrument items (Supardi, 2015 ).

The same thing is explained by Karwono and Mularsih (2017) related to the steps for developing an assessment instrument as follows: (1) determining goals, (2) determining an assessment plan, (3) preparing assessment instruments, (4) collecting data or information, (5 ) analysis and interpretation, and (6) follow-up.

Yusuf (2015) explains that the stages in developing an assessment instrument as follows: (1) setting the assessment objectives, (2) developing specifications, (3) developing the scope of the exam, (4) selecting the type of item, (5) preparing for the preparation of test items, (6) compiling test items, (7) reviewing test items, (8) administering tests, (9) scoring and processing tests, (10) interpreting tests, and (11) using tests to improve learning activities.

The steps for developing an assessment instrument are described by Djaali and Muljono (2004) as follows: (1) the synthesis of the theories studied and then the constructs of the formulated concepts are formulated, (2) based on the constructs that have been formulated, the dimensions and indicators to be measured are developed ( 3) create a grid of instruments, (4) determine the magnitude or parameters in the continuum range, (5) write the items of the instrument, (6) carry out theoretical validation by experts, (7) revision or improvement based on suggestions from experts or focus groups discussion, (8) limited instrumentation for testing purposes, (9) instrument testing in the field as an empirical validation process, (10) reliability coefficient 
testing, and (11) assembling valid instrument items to be used as final instruments.

Arikunto (2010) describes that the steps for developing an assessment instrument are: (1) determining the purpose of conducting an assessment, (2) determining restrictions on the material to be assessed, (3) formulating specific instructional objectives for each material, (4) setting all instructional objectives specifically in the table, (5) compiling a specification table, and (6) writing down the questions. Furthermore, Surapranata (2005) describes the steps for developing an assessment instrument as follows: (1) determining objectives, (2) preparing grids, (3) writing questions, (4) reviewing and revising questions, (5) testing questions, and (6) final question assembly.

Meanwhile, Triana (2013:131) explains the steps for developing dance assessment instruments as follows: (1) compiling conceptual definitions and operational definitions based on theoretical studies, (2) making a grid of dance assessment instruments, (3) determining the scale assessment that will be used along with its descriptors, (4) prepare clear instructions or instructions related to the details in conducting the assessment, and (5) provide a sheet of observation instruments used when assessing dance performances.

The assessment model for dance can be seen from the type of dance being assessed, in the sense that the assessment model for traditional dance is different from the assessment model for modern dance. The difference is seen from the aspects that are assessed from the dance, which includes the art of dance itself, the art of music supporting the dance, the fashion used in dance performances.

The dance assessment model developed so far to assess traditional dance is generally known as the Tri "W" or 3W, namely: Wirasa (expression/inspiration), Wiraga (body flexibility, conformity of body shape to the dance performed). , and Wirama (dance accuracy to the rhythm of the dance music).

The assessment model of modern dance developed by Triana (2014) with assessment aspects consisting of: (1) song/beat selection, (2) similarity, (3) energetic/powerful movement, (4) choreographic composition, (5) difficulty level, (6) harmonization with vocals, and (7) accuracy of lips and audio. Furthermore, Kusnadi and Puspitorini (2006) explained the dance ability assessment model as follows: (1) body work, (2) character, and (3) choreography

\section{RESEARCH METHOD}

This research develops a product that is feasible, effective and practical to use in the assessment of Malay Dance. The product developed in this study is a Malay dance assessment model designed by applying research and development (R\&D) developed by Plomp with the following stages: needs analysis stage, design stage, realization stage and evaluation and revision stage.

The research was conducted in Education outside the Dance Studio of North Sumatra which is spread across the districts/cities of Medan, Langkat, Binjai, Deli Serdang, Serdang Bedagai, Batubara and Asahan. The implementation of the research begins in February April 2021. The population in this study is all dance studios located in the regency/city that is the research location. Each district / city set 3 dance studios. The sampling was done by simple random sampling technique.

The data collection instrument used was a questionnaire used to collect data related to the product feasibility assessment obtained from experts and test subjects. The data analysis techniques carried out in testing the validity of the assessment instrument were carried out as follows: (1) testing using a rater validation which was quantitatively measured by looking for index $\mathrm{V}$ from Aiken, and (2) testing the validity of the Malay dance assessment instrument using the product formula. moments. The data analysis technique used in testing the reliability of the assessment instrument is carried out as follows: (1) testing using Interrater validation (between assessors), and (2) testing the reliability of the assessment instrument using the Cronbach Alpha formula. Furthermore, the data analysis technique in testing the effectiveness of the dance assessment model was used statistical analysis t-test.

\section{RESULT AND DISCUSSION}

\subsection{Result}

Figures and tables should be placed either at the top or bottom of the page and close to the text referring to them if possible. The results of the expert validation feasibility assessment of the dance assessment instrument are described as follows: 
Table 1. Expert Assessment Score Evaluation of Dance Art Assessment Instruments

\begin{tabular}{|c|l|c|}
\hline No & Assessment Aspects & Score \\
\hline 1 & Instructions for using & 4,00 \\
\hline 2 & Construction & 4,00 \\
\hline 3 & Language & 3,70 \\
\hline \multicolumn{2}{|c|}{ Average } & 3,90 \\
\hline
\end{tabular}

Based on the data in Table 1, it can be seen that the assessment of the feasibility of the evaluation expert on the dance assessment instrument obtained an average score of 3.90 and was in the very feasible category.

Table 2. Material Expert Assessment Score Against Dance Art Assessment Instruments

\begin{tabular}{|c|l|r|}
\hline No & Assessment Aspects & Score \\
\hline 1 & Instructions for using & 4,00 \\
\hline 2 & Construction & 3,80 \\
\hline 3 & Language & 4,00 \\
\hline \multicolumn{2}{|c|}{ Average } & 3,93 \\
\hline
\end{tabular}

Based on the data in Table 2, it can be seen that the material expert's feasibility assessment of the dance assessment instrument obtained an average score of 3.93 and was in the very feasible category.

Table 3. Languages Expert Assessment Score Against Dance Art Assessment Instruments

\begin{tabular}{|r|l|r|}
\hline \multicolumn{1}{|c|}{ No } & Assessment Aspects & Score \\
\hline 1 & Language Rules & 3,40 \\
\hline 2 & Legibility & 3,30 \\
\hline \multicolumn{2}{|c|}{ Average } & 3,35 \\
\hline
\end{tabular}

Based on the data in Table 3, it can be seen that the linguist's assessment of the dance assessment instrument obtained an average score of 3.35 and was in the proper category without revision.

Table 4. Result of Individual Trial on Dance Art Assessment Instruments

\begin{tabular}{|c|l|r|}
\hline No & Assessment Aspects & Score \\
\hline 1 & Instructions for using & 3,40 \\
\hline 2 & Construction & 3,17 \\
\hline 3 & Language & 3,55 \\
\hline \multicolumn{2}{|c|}{ Average } & 3,37 \\
\hline
\end{tabular}

Based on the data in Table 4, it can be seen that the results of individual trials of dance assessment instruments obtained a cumulative average score of 3.37 with a feasible category without revision.
Table 5. Result of Small Group Trial Against Dance Art Assessment Instruments

\begin{tabular}{|r|l|r|}
\hline No & Assessment Aspects & Score \\
\hline 1 & Instructions for using & 3,56 \\
\hline 2 & Contruction & 3,36 \\
\hline 3 & Language & 3,43 \\
\hline \multicolumn{2}{|c|}{ Average } & 3,45 \\
\hline
\end{tabular}

Referring to the Table 5, it can be seen that the results of small group trials on dance assessment instruments obtained a cumulative average score of 3.45 with a decent category without revision.

Table 6. Results of Field Group Trials on Dance Art Assessment Instruments

\begin{tabular}{|r|l|r|}
\hline \multicolumn{1}{|c|}{ No } & Assessment Aspects & Score \\
\hline 1 & Instructions for using & 3,40 \\
\hline 2 & Contruction & 3,38 \\
\hline 3 & Language & 3,60 \\
\hline \multicolumn{2}{|c|}{ Average } & 3,46 \\
\hline
\end{tabular}

Based on the data in Table 6, it can be seen that the results of field group trials on dance assessment instruments obtained an average score of 3.46 with a decent category without revision.

The results of testing the validity of the Malay dance assessment instrument with the Aiken formula show that all the items of the assessment instrument are valid because the value of the $\mathrm{V}$ index obtained is between 0 1. Furthermore, empirically testing is the validity of the dance assessment instrument using the product moment correlation formula shows all the items of the assessment instrument. is valid.

Testing the reliability of the Malay dance assessment instrument was carried out by testing the interrater reliability (between assessors) and Cronbach's Alpha formula. The results of the interrater reliability test show the reliability coefficient is 0.88 . Furthermore, referring to Surapranata (2004) that an instrument is said to have reliability if the reliability coefficient is $0.70-0.80$ Therefore, the reliability coefficient is 0.880 .70 . The Malay dance assessment instrument developed is reliable.

The results of the reliability test of the dance assessment instrument with the Cronbach Alpha formula showed a reliability coefficient of 0.95 . Furthermore, by referring to Surapranata (2004) an instrument is said to have reliability if the reliability coefficient is between $0.70-0.80$. Thus, it can be seen 
that the reliability coefficient is 0.950 .70 , so it can be concluded that the dance assessment instrument developed is reliable.

Testing the effectiveness of the dance assessment model was carried out using the $t$ test. The results of testing the effectiveness of the developed dance assessment model obtained the $\mathrm{t}$-count value of 4.18 and the t-table value with $\mathrm{N}=59 \alpha=0.05$, namely 1.98 . Because the value of $t_{\text {count }}>t_{\text {table }}$ value, Ho is rejected, it can be concluded that the developed dance assessment model has a real effect on the students' learning outcomes of dancing.

\subsection{Discussion}

The results of the feasibility validation conducted by the evaluation expert on the assessment instrument for Malay dance showed an average score of 3.90 in the very feasible category. The material expert's assessment of the Malay dance assessment instrument showed an average score of 3.93 in a very decent category. Furthermore, the linguist's assessment of the Malay dance assessment instrument showed an average score of 3.35 in the appropriate category without revision. Observing the average score given by evaluation experts, material experts and linguists on the assessment instrument for Malay Dance, cumulatively, an average score of 3.72 was obtained in a very decent category. Referring to the hypothesis testing of the feasibility of dance assessment instruments by experts, namely the alternative hypothesis is accepted if the average score is $>3.00$. Because the cumulative average score of the expert feasibility assessment on the assessment instrument is $3.72>3.00$, it can be concluded that the dance assessment instrument is feasible to use. This means that the Malay dance assessment instrument developed reflects the level of feasibility to be used, but of course by accommodating suggestions for improvement submitted by experts.

The role of the Malay dance assessment instrument is as a learning resource for dance instructors in assessing the dancing competence of students. Therefore, the construction contained in the assessment instrument for Malay dance can truly measure the Malay dance competence of students. In terms of assessment instruments, Malay dance has included aspects of Malay dance, namely the 5R (rukun, rentak, resam, rasa and ribus).

In addition, the assessment instrument for Malay dance is intended for dance instructors, so the aspects of meeting the rules of language and its readability are urgently needed to be considered. Fulfillment of language rules and legibility is important in the development of assessment instruments so that dance instructors can easily understand them. The urgency of legibility in Malay dance assessment instruments from the perspective of dance instructors as users is because students have individual differences related to training experience, training followed, differences in cognitive style and so on. This indicates that dance instructors have different characteristics from one another so that the readability of the dance assessment instrument is an important factor to consider because it will make it easier for the dance instructor to understand the assessment instrument.

The findings of this study support the findings of previous studies including: (1) research by Saputra, Jampel and Suwatra (2021) on the development of knowledge competency assessment instruments. and (2) research by Hasan, Aulia and Herawati (2020) on the development of an instrument for assessing students' thinking skills.

The results of testing the validity of the dance assessment instrument using the Aiken formula, namely by looking for index $\mathrm{V}$, then all the items of the assessment instrument show validity. Likewise, the results of testing the validity of the dance assessment instrument using the product moment correlation formula, namely by looking for the $r$ coefficient, then all the items of the assessment instrument show validity.

The results of the test of the reliability of the dance assessment instrument using the interrater reliability test (between assessors) obtained 0.88. Furthermore, the results of testing the reliability of dance assessment instruments using the Alpha Cronbach formula obtained 0.95. Furthermore, if we examine the explanation of Surapranata (2004) that an instrument is said to have reliability if the reliability coefficient is $0.70-0.80$. Because the reliability coefficients are 0.88 and 0.95 0.70 , the Malay dance assessment instrument developed is reliable.

It is urgent to test the validity and reliability of this instrument as a requirement to say that a good instrument must have a level of validity and reliability. This is confirmed by Arikunto (2010) that the assessment instrument must meet the following requirements: (1) validity means that the assessment instrument developed is appropriate to measure what is to be measured, and (2) reliability means that the 
developed assessment instrument shows determination on the results achieved.

The validity testing of the dance assessment instrument using the Aiken formula by looking for index $\mathrm{V}$ is a test of the validity of the content of the assessment instrument developed through the assessment given by the evaluator, so it can be said that the content or material already has the accuracy and suitability of the construction to measure the dancing competence of participants. educate. Furthermore, testing the validity of dance assessment instruments using the product moment correlation formula is an empirical validity test or also known as concurrent. This empirical validity shows the relationship between test scores and those achieved with the current state.

The reliability testing was carried out using interrater testing (between assessors) and testing with Cronbach's Alpha formula is an internal consistency reliability test. Internal consistency testing is related to the elements that make up an instrument, namely the items that make up the instrument.

The product developed, namely the dance assessment instrument model is a printed learning resource that is planned or by design used in the assessment of students' Malay dancing competence. Related to this planned learning resource (by design), AECT (1986) explains that learning resources can be grouped into two parts, namely: (1) planned learning resources (by design), namely all learning resources that have been specifically developed as components of an instructional system to provide targeted and formal learning facilities; and (2) learning resources because they are utilized (by utilization), namely sources that are not specifically designed for learning purposes but can be found, applied and used for learning purposes.

The findings of this study are in line with the findings of previous studies related to the effectiveness of the application of the assessment model carried out by Rosnawati (2017) in developing an instrument for assessing the ability to dance in SMA 3 Watansoppeng students in terms of theoretical and empirical aspects. The results of the development of the dancing ability assessment instrument for students were content valid through 3 dimensions, namely bodybuilding, performance, and choreography as well as 12 indicators, namely, body exercise dimensions including: flexibility, balance, agility, and endurance. Innate dimensions include: movement techniques, rhythm, cohesiveness, and inspiration. The dimensions of choreography include: form, atmosphere, accompaniment, and makeup. Empirically, the results of developing the dancing ability assessment instrument for students have been valid through field trials and are reliable based on an intrarater approach.

Associated with the results of testing the validity and reliability of this dance assessment instrument, so that it can be used optimally, the ability of dance instructors to consistently apply this assessment instrument in the implementation of the assessment of the competence of Malay dance students. If the level of consistency of dance instructors continues to increase, it will have an impact on the level of effectiveness of the use of this dance assessment instrument model, thus, the objectives and principles of assessment related to measuring the competence of Malay dance students by using the dance assessment instrument model also increase.

The ability of dance instructors to manage learning and assess students' dancing competence is actually implemented in activities starting learning, managing learning activities, organizing student time and learning facilities, and carrying out assessment activities. Related to this, there are several things that need to be considered and improved by dance instructors, namely helping students in mastering learning materials, providing opportunities and asking students to discuss and ask dance instructors; guide, encourage and direct students to practice.

If further investigated, it was found that related to the ability of dance instructors to carry out assessments, there was a gap between the instructor's mastery of the theories that underlie the developed dance assessment instrument model and the dance instructor's ability to practice assessment in the daytime. It is often found that the words/explanations of the dance instructor are different from their actions. For example, dance instructors state that students are attempted to be able to construct their dance knowledge and skills, but dance instructors explain in full before students try to carry out these activities. For this reason, the role of dance instructors as facilitators, motivators, moderators, consultants, and designers is important to improve.

Regarding the role of dance instructors in managing learning and carrying out assessments described by Joyce and Weil (2003) that for the creation of this social system and support system, the role or task of the educator is to ensure that the questions are phrased properly so that the questions can be answered yes. or not and the substance of the question does not require educators to do research and ask students to rephrase the question and emphasize/show important points. 
The results of testing the effectiveness of the dance assessment model compare the learning outcomes of the experimental class using the developed assessment instrument model with the learning outcomes of the control class using the conventional ( $3 \mathrm{~W}$ ) assessment models. The calculation results show the $t_{\text {count }}$ value $=$ 4.18 while the ttable price $\alpha=0.05$ is 1.98 . Because the value of $t_{\text {count }}>t_{\text {table }}$ value, Ho is rejected, it can be concluded that the developed dance assessment model has a real effect on student learning outcomes.

Related to the effectiveness of the use of this dance assessment instrument so that it can be used optimally, the ability of dance instructors to consistently apply this assessment instrument in the implementation of the Malay dance competency assessment of students. If the level of consistency of dance instructors continues to increase, it will have an impact on the level of effectiveness of the use of this dance assessment instrument model, thus, the objectives and principles of assessment related to measuring the competence of Malay dance students by using the dance assessment instrument model also increase.

The ability of dance instructors to manage learning and assess students' dancing competence is actually implemented in activities starting learning, managing learning activities, organizing student time and learning facilities, and carrying out assessment activities. Related to this, there are several things that need to be considered and improved by dance instructors, namely helping students in mastering learning materials, providing opportunities and asking students to discuss and ask dance instructors; guide, encourage / direct students to practice.

\section{CONCLUSION}

Based on the research findings, it can be concluded as follows:

a. The assessment model developed is a dance assessment model by carrying out the 5R (rukun rentak, resam, rasa and ribus) to assess the Malay dance competence of students.

b. The results of testing the validity of the dance assessment instrument with the Aiken formula and product moment correlation show that the overall instrument item is valid. The results of testing the reliability of dance assessment instruments by calculating the interrater reliability coefficient (between assessors) obtained the value of the dance reliability coefficient of 0.88 . Furthermore, the results of testing the reliability of dance assessment instruments with the Cronbaach Alpha formula show a dance reliability coefficient of 0.95 . The reliability coefficients of 0.88 and 0.95 indicate high reliability, this means that the Malay dance assessment instrument developed is reliable.

c. The assessment model developed has a level of effectiveness on the achievement of students dancing competence, this can be seen from the calculation results showing the $t_{\text {count }}=4.18$ while the $\mathrm{t}_{\text {table }}$ price $\alpha=0.05$ is 1.98 .

\section{REFERENCES}

[1]. Anggraini, Dwi. dan Hasnawati. (2016). Perkembangan Seni Tari: Pendidikan Dan Masyarakat. Jurnal: Jurnal Ilmiah Pendidikan Guru Sekolah Dasar, Vol. 9 No. 3. h. 287-293.

[2]. Arikunto, Suharsimi. (2010). Dasar-Dasar Evaluasi Pendidikan, Jakarta: Bumi Aksara.

[3]. Djaali dan Muljono, P. (2004). Pengukuran Dalam Bidang Pendidikan. Jakarta: Program Pascasarjana Universitas Negeri Jakarta.

[4]. Evadila. (2017) Estetika Tari Zapin Pecah Dua Belas Di Kecamatan Pangkalan Kerinci Kabupaten Pelalawan Provinsi Riau. Jurnal KOBA Volume 4, No 1, h. 16-24.

[5]. Hasan, Sri Wahyuni., Auliah, Army dan Herawati, Netti. Pengembangan Instrumen Penilaian Kemampuan Berpikir Kritis Siswa SMA. Jurnal: Chemistry Education Review, 2020 Vol. 3, No. 2

[6]. Karwono dan Mularsih, Heni. (2017). Belajar dan Pembelajaran Serta Pemanfaatan Sumber Belajar. Jakarta: Rajawali Pers.

[7]. Kunandar. 2013. Penilaian Authentik (Penilaian Hasil Belajar Peserta Didik Berdasarkan Kurikulum 2013). Jakarta: Rajawali Pers.

[8]. Kusnadi dan Puspitorini. (2006). Pengembangan Model Penilaian Hasil belajar Seni Tari. Yogyakarta: FBS UNY.

[9]. Nurnaningsih. (2018). Pengajaran Tari Zapin Beradat Pada Siswa Kelas Vii.A SMPN XII Koto Kampar Kabupaten Kampar Provinsi Riau. Jurnal: Koba, Volume 5 Nomor 1, h. 81-86.

[10]. Pasaribu, Heni Ratam. (2017) Pembelajaran Apresiasi Tari Mak Inang Melalui Media 
Audiovisual Terhadap Penilaian Tari Pada Siswa Di Kelas X SMA Santa Maria Medan. Jurnal Gesture Vol 6. No. 2 h. 1-9.

[11]. Putri, Firta Meilinda., dan Yanuartuti, Setyo. (2018). Pembelajaran Seni Budaya (Seni Tari) Tahun Pelajaran 2016/2017 Di SMA Negeri 1 Kertosono. e-Journal Universitas Negeri Surabaya, h. $1-15$.

[12]. Rosnawati. (2017). Pengembangan Instrumen Penilaian Kemampuan Menari Pada Peserta Didik SMA Negeri 3 Watansoppeng Kabupaten Soppeng. Jurnal: PEP Educational Assessment Volume 1 Nomor 1. h. 59-65.

[13]. Ruslan, Irma Dewi. (2018). Peningkatan Motivasi Belajar Seni Tari Persembahan Melayu Melalui Media Video Bagi Siswa Kelas VIII SMP Negeri 1 Pekanbaru, Jurnal: Pendidikan Tambusai, Volume 2 Nomor 4. h. 926-936.

[14]. Saputra, Putu Agus Adi., Jampel, I Nyoman dan Suwatra, Ignatius I Wayan. Pengembangan Instrumen Penilaian Kompetensi Pengetahuan IPA Siswa Sekolah Dasar. Journal for Lesson and Learning Studies Volume 4, Number 1, 2021

[15]. Supardi. (2015). Penilaian Autentik, Konsep dan Aplikasi. Jakarta: Rajagrafindo Persada.

[16]. Triana, Dinny Devi. (2014) Model Penilaian Kinestetik dalam Menilai Tari I-Pop (Modern Dance). Jurnal: Panggung Vol. 24 No. 1, Maret 2014, h. 71-83.

[17]. Triana, D. D. (2012). Kinesthetic Assessment of Dance Arts. Jurnal Evaluasi Pendidikan, 3(1), 78949.

[18]. Triana, D. D. (2006). Skala Pengukuran sebagai Alat Evaluasi dalam Menilai Tari Karya Mahasiswa (Measurement Scale as Instrument of Evaluation in Assessing Student's Piece of Dance). Harmonia: Journal of Arts Research and Education, 7(2).

[19]. Yaumi, M. 2015. Prinsip-Prinsip Desain Pembelajaran. Jakarta: Kencana Prenada Media Group.

[20]. Yusuf, A. Muri. (2015). Asesmen Dan Evaluasi Pendidikan. Jakarta: Prenada Media Group.

[21]. Zulfahmi, Muhammad. (2016). Interaksi Dan Inter Relasi Kebudayaan Seni Melayu Sebagai Sebuah
Proses Pembentukan Identitas. Jurnal: Ekspresi Seni. Jurnal Ilmu Pengetahuan Dan Karya Seni. Volume 18, Nomor 2, h. 317-323. 